\title{
Let's just do what we must
}

\author{
Gaetano Rocco, MD, FRCSEd
}

\footnotetext{
From the Division of Thoracic Surgery, Thoracic Department, Istituto Nazionale Tumori, IRCCS, Fondazione G. Pascale, Naples, Italy.

Disclosures: G.R. is a consultant for Scanlan International, St Paul, Minn.

Received for publication Feb 25, 2018; accepted for publication Feb 28, 2018; available ahead of print March 23, 2018.

Address for reprints: Gaetano Rocco, MD, FRCSEd, Division of Thoracic Surgery, Thoracic Department, Istituto Nazionale Tumori, IRCCS, Fondazione G. Pascale, Via Semmola 81 80131, Naples, Italy (E-mail: g.rocco@ istitutotumori.na.it).

J Thorac Cardiovasc Surg 2018;156:374-5

$0022-5223 / \$ 36.00$

Copyright $(2018$ by The American Association for Thoracic Surgery

https://doi.org/10.1016/j.jtcvs.2018.02.069
}

The excellent editorial by Kruser and colleagues ${ }^{1}$ about the article by Sun and colleagues ${ }^{2}$ is rightfully centered on the postoperative options for $\mathrm{N} 2$ disease and the outcome differences noted when occult N2 is treated compared with $\mathrm{N} 2$ identified at preoperative staging. The analysis of the literature shows that, irrespective of the $\mathrm{N} 2$ subsets, mediastinal nodal involvement carries a significant risk for distant recurrence. ${ }^{1}$ Conversely, the efficacy of preoperative staging predicts the likelihood of mediastinal local recurrence after surgical resection. ${ }^{1}$ Despite the presence of specific guidelines, ${ }^{3,4}$ the adoption and completeness of both preoperative staging and intraoperative mediastinal nodal dissection may vary according to geographic areas, institutions, and individual surgeons. ${ }^{5}$ One example for all is the different approach to preoperatively identified single station $\mathrm{N} 2$, which in many reported series is associated with a favorable prognostic outlook after primary resection. ${ }^{5}$ However, the common denominator of an oncologically acceptable lung resection remains the performance of a thorough lymphadenectomy with nodal sampling or a complete nodal dissection. Although the impact of either modality on overall survival was not proven in American College of Surgery Oncology Group Z0030, the improved yield in terms of mediastinal staging represents the ground for an optimal choice for possible adjuvant treatments. ${ }^{6}$ Liang and associates ${ }^{7}$ recently attempted to identify the threshold of the number of lymph nodes to be removed during surgery associated with precise staging and long-term survival. Data from 5706 patients were obtained from a Chinese multiinstitutional registry and validated by 38,806 patients from the US SEER database. ${ }^{7}$ The authors concluded that, after adjusting for confounders, the greater the number of nodes removed at lung surgery the more precise was postoperative staging, as well as better overall survival in both $\mathrm{N} 0$ and $\mathrm{N}+$ disease. $^{7}$ In particular, the number of lymph nodes representing the cutoff number to define the quality of the lymphadenectomy was 16 ; this number originated from the sum of lymph nodes removed intraoperatively by the

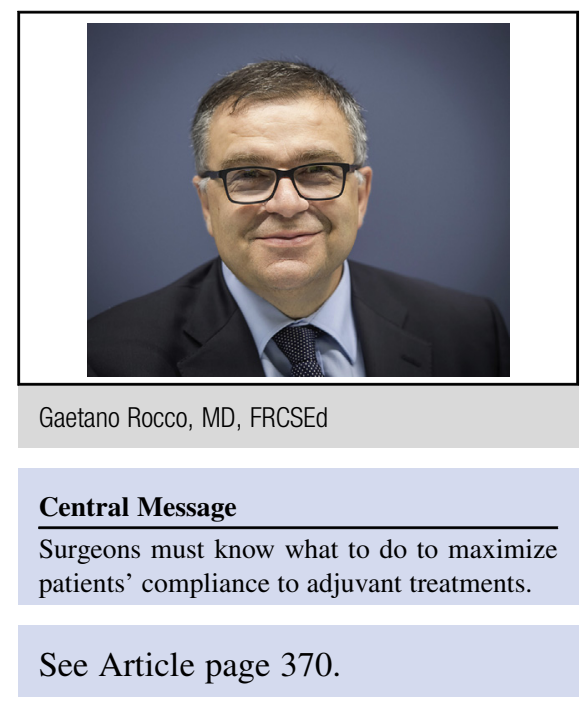

surgeon added to the ones identified by the pathologist postoperatively. ${ }^{7}$ In the quest for tailoring our surgical procedure to the individual patient who may be subjected to adjuvant treatments, we currently have sufficient evidence to select the parenchymal extent of the resection, and more information will come from the forthcoming trials of lobectomy compared with sublobar resections. ${ }^{8,9}$ In this setting, it is a matter of debate whether the preferred approach should be through video-assisted thoracic surgery, ${ }^{10-12}$ but the reduced surgical time, intraoperative blood loss, chest drain, and length of hospital stay are appealing and solid arguments in favor of thoracoscopy. ${ }^{13}$ In addition, Enhanced Recovery After Surgery protocols are meant to ensure prompt recovery after surgery, thereby further contributing to the compliance to chemotherapy. ${ }^{14}$

Surgery retains a definite role in managing patients with $\mathrm{N} 2$ non-small cell lung cancer, ${ }^{15}$ and we have the unique opportunity to modulate indications and techniques to fit the patients' potential needs for postoperative treatments. ${ }^{7,8,16}$ It is just a matter of doing what we must.

\section{References}

1. Kruser TJ, Mohindra N, DeCamp MM. One size does not fit all: nuances in postoperative N2 NSCLC management. J Thorac Cardiovasc Surg. 2018;156:370-3.

2. Sun JM, Noh JM, Oh D, Kim HK, Lee SH, Choi YS, et al. Randomized phase II trial comparing chemoradiotherapy with chemotherapy for completely resected unsuspected N2-positive non-small cell lung cancer. J Thorac Oncol. 2017;12: 1806-13.

3. Turna A, Melek H, Kara HV, Kılıç B, Erşen E, Kaynak K. Validity of the updated European Society of Thoracic Surgeons staging guideline in lung cancer patients. J Thorac Cardiovasc Surg. 2018;155:789-95.

4. Lardinois D, De Leyn P, Van Schil P, Porta RR, Waller D, Passlick B, et al. ESTS guidelines for intraoperative lymph node staging in non-small cell lung cancer. Eur J Cardiothorac Surg. 2006;30:787-92. 
5. Rocco G, Nason K, Brunelli A, Varela G, Waddell T, Jones DR. Management of stage IIIA (N2) non-small cell lung cancer: a transatlantic perspective. J Thorac Cardiovasc Surg. 2016;151:1235-8.

6. Darling GE, Allen MS, Decker PA, Ballman K, Malthaner RA, Inculet RI, et al. Randomized trial of mediastinal lymph node sampling versus complete lymphadenectomy during pulmonary resection in the patient with N0 or N1 (less than hilar) non-small cell carcinoma: results of the American College of Surgery Oncology Group Z0030 Trial. J Thorac Cardiovasc Surg. 2011;141:662-70.

7. Liang W, He J, Shen Y, Shen J, He Q, Zhang J, et al. Impact of examined lymph node count on precise staging and long-term survival of resected non-small-cell lung cancer: a population study of the US SEER database and a Chinese multiinstitutional registry. J Clin Oncol. 2017;35:1162-70.

8. Dai C, Shen J, Ren Y, Zhong S, Zheng H, He J, et al. Choice of surgical procedure for patients with non-small-cell lung cancer $\leq 1 \mathrm{~cm}$ or $>1$ to $2 \mathrm{~cm}$ among lobectomy, segmentectomy, and wedge resection: a population-based study. J Clin Oncol. 2016;34:3175-82.

9. Kohman LJ, Gu L, Altorki N, Scalzetti E, Veit LJ, Wallen JM, et al. Biopsy first: lessons learned from Cancer and Leukemia Group B (CALGB) 140503. J Thorac Cardiovasc Surg. 2017; 153:1592-7.

10. Petersen RP, Pham D, Burfeind WR, Hanish SI, Toloza EM, Harpole DH Jr, et al. Thoracoscopic lobectomy facilitates the delivery of chemotherapy after resection for lung cancer. Ann Thorac Surg. 2007;83:1245-9.
11. Licht PB, Schytte T, Jakobsen E. Adjuvant chemotherapy compliance is not superior after thoracoscopic lobectomy. Ann Thorac Surg. 2014;98: 411-5.

12. Lee JG, Cho BC, Bae MK, Lee CY, Park IK, Kim DJ, et al. Thoracoscopic lobectomy is associated with superior compliance with adjuvant chemotherapy in lung cancer. Ann Thorac Surg. 2011;91:344-8.

13. Yan TD, Black D, Bannon PG, McCaughan BC. Systematic review and metaanalysis of randomized and nonrandomized trials on safety and efficacy of video-assisted thoracic surgery lobectomy for early-stage non-small-cell lung cancer. J Clin Oncol. 2009;27:2553-62.

14. Rogers LJ, Bleetman D, Messenger DE, Joshi NA, Wood L, Rasburn NJ, et al. The impact of enhanced recovery after surgery (ERAS) protocol compliance on morbidity from resection for primary lung cancer. J Thorac Cardiovasc Surg. December 19, 2017 [Epub ahead of print].

15. Yang CF, Kumar A, Gulack BC, Mulvihill MS, Hartwig MG, Wang X, et al Long-term outcomes after lobectomy for non-small cell lung cancer when unsuspected pN2 disease is found: A national cancer data base analysis. J Thorac Cardiovasc Surg. 2016;151:1380-8.

16. Zhang Z, Mostofian F, Ivanovic J, Gilbert S, Maziak DE, Shamji FM, et al. Al grades of severity of postoperative adverse events are associated with prolonged length of stay after lung cancer resection. J Thorac Cardiovasc Surg. 2018;155 798-807. 